\title{
Supply Curves for Rooftop Solar PV-Generated Electricity for the United States
}

Technical Report NREL/TP-6A0-44073

November 2008

Paul Denholm and Robert Margolis

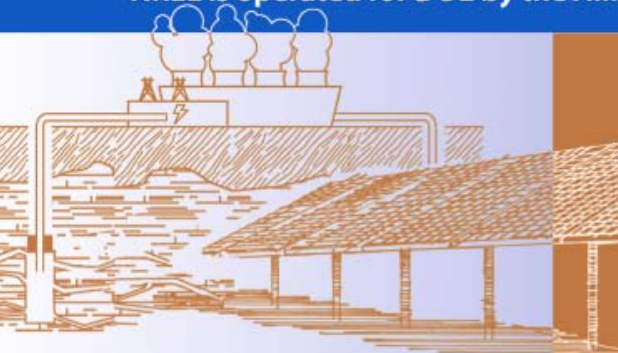




\section{Supply Curves for Rooftop Solar PV-Generated Electricity for the United States}

Technical Report NREL/TP-6A0-44073

November 2008

\section{Paul Denholm and Robert Margolis}

Prepared under Task No. PVB7.6301

National Renewable Energy Laboratory 1617 Cole Boulevard, Golden, Colorado 80401-3393 303-275-3000 • www.nrel.gov

NREL is a national laboratory of the U.S. Department of Energy Office of Energy Efficiency and Renewable Energy

Operated by the Alliance for Sustainable Energy, LLC

Contract No. DE-AC36-08-GO28308

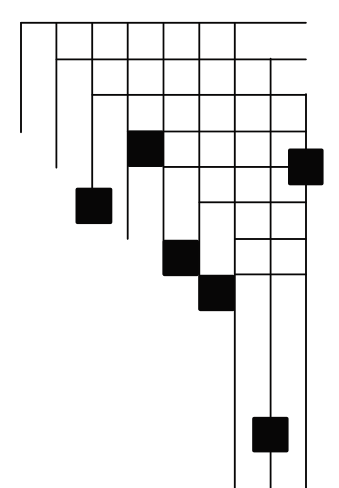




\section{NOTICE}

This report was prepared as an account of work sponsored by an agency of the United States government. Neither the United States government nor any agency thereof, nor any of their employees, makes any warranty, express or implied, or assumes any legal liability or responsibility for the accuracy, completeness, or usefulness of any information, apparatus, product, or process disclosed, or represents that its use would not infringe privately owned rights. Reference herein to any specific commercial product, process, or service by trade name, trademark, manufacturer, or otherwise does not necessarily constitute or imply its endorsement, recommendation, or favoring by the United States government or any agency thereof. The views and opinions of authors expressed herein do not necessarily state or reflect those of the United States government or any agency thereof.

Available electronically at http://www.osti.gov/bridge

Available for a processing fee to U.S. Department of Energy and its contractors, in paper, from:

U.S. Department of Energy

Office of Scientific and Technical Information

P.O. Box 62

Oak Ridge, TN 37831-0062

phone: 865.576 .8401

fax: 865.576 .5728

email: mailto:reports@adonis.osti.gov

Available for sale to the public, in paper, from:

U.S. Department of Commerce

National Technical Information Service

5285 Port Royal Road

Springfield, VA 22161

phone: 800.553 .6847

fax: 703.605.6900

email: orders@ntis.fedworld.gov

online ordering: http://www.ntis.gov/ordering.htm 


\section{Table of Contents}

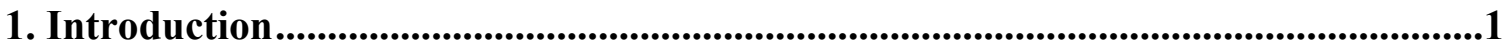

2. A Basic Rooftop PV Supply Curve.............................................................................2

2.1 Solar Resource Data and Simulations........................................................... 2

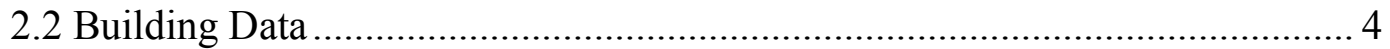

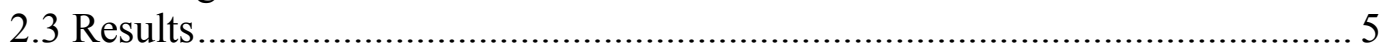

3. Supply Curve Variations.........................................................................10

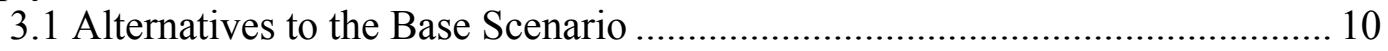

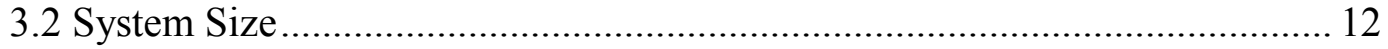

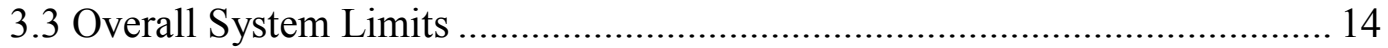

3.4 Other PV Deployment Options .................................................................. 15

4. Discussion and Conclusions ....................................................................................16

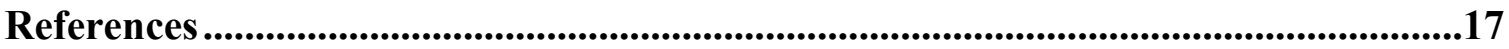

\section{List of Tables and Figures}

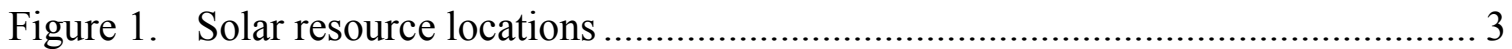

Figure 2. PV rooftop capacity supply curve for U.S. buildings in 2007 ......................... 6

Figure 3. Distribution of PV rooftop capacity costs for U.S. buildings in 2007 .............. 7

Figure 4. PV rooftop energy supply curve for U.S. buildings in 2007 .......................... 8

Figure 5. Distribution of PV rooftop energy costs for U.S. buildings in 2007 ................ 8

Figure 6. Combined PV rooftop energy supply curve for U.S. buildings in 2007 ........... 9

Table 1. Assumptions for Alternative Scenarios ..................................................... 10

Figure 7. Alternative cases for residential roof PV supply curve ................................. 11

Figure 8. Alternative cases for commercial roof PV supply curve ............................... 11

Figure 9. Alternative case combined PV rooftop energy supply curve for U.S.

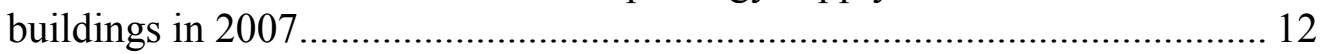

Figure 10. Size-restricted PV rooftop capacity supply curve for residential buildings ... 13

Figure 11. Fractional energy PV rooftop supply curve for three U.S. interconnects....... 15 


\section{Introduction}

Energy supply curves attempt to estimate the relationship between the cost of an energy resource and the amount of energy available at or below that cost. In general, an energy supply curve is a series of step functions with each step representing a particular group or category of energy resource. The length of the step indicates how much of that resource is deployable or accessible at a given cost. Energy supply curves have been generated for a number of renewable energy sources including biomass fuels (Gallagher et al. 2003), wind (Kline et al. 2008), and geothermal (Petty and Porro 2007), as well as conservation technologies (Rosenfeld et al. 1993).

Generating a supply curve for solar photovoltaics (PV) has particular challenges due to the nature of the resource. The United States has a massive solar resource base - many orders of magnitude greater than the total consumption of energy. A common expression of this resource base is the demonstration that placing a PV array in a single large county in Nevada would provide all the energy required by the United States. This very simple case would imply an essentially flat supply curve.

In reality, this example does not address the need to transmit this energy, nor the challenges of solar resource intermittency. The placement of PV in a single location also ignores one of PV's greatest assets: the ability to place PV generation at or very close to load. By deploying photovoltaics on building rooftops, there is little to no cost associated with land, and the system is deployed at the point of use, which minimizes transmission and distribution requirements and losses.

In this report, we examine several possible methods for generating PV supply curves based exclusively on rooftop deployment. We begin by introducing a framework methodology for a basic supply curve based on estimated distribution of population and buildings, rooftop availability and orientation, and geographical variation in resource. We then discuss limitations to this basic methodology and introduce alternative supply curves that consider additional factors - changes in PV efficiency and configuration, rooftop availability, and grid limitations - while emphasizing the data and methodological limitations to each approach. The resulting curves potentially could be used as inputs to other models or as stand-alone results. 


\section{A Basic Rooftop PV Supply Curve}

A supply curve consists of a series of discrete steps, each step having two components: the cost of an energy resource and the capacity or energy available at that cost. The first component (the cost of energy from PV) may be expressed as the "levelized cost of electricity" (LCOE) where

$$
\mathrm{LCOE}=\text { annualized cost/annual energy production }
$$

The annualized cost is a function of system capital costs, financing parameters, and operation and maintenance (O\&M). The second component (annual energy production) depends on the solar resource, PV system performance, and system configuration (including orientation and potential use of tracking arrays). If there is no regional variation in the annualized cost for a PV system, then the variation in LCOE from one location to another is based solely on the variation in annual energy production.

For example, the typical annual output of a flat-mounted $1 \mathrm{~kW}$ system in San Diego, California, is about 1,310 kilowatt hours ( $\mathrm{kWh}$ ), while the same system in Seattle, Washington, would produce about $850 \mathrm{kWh}{ }^{1}$ As a result, the LCOE of the Seattle system is about 1.5 times greater than the San Diego System, ignoring any differences in financing and incentives.

The variation in energy production resulting solely from insolation and orientation can form the basis for a simple supply curve that expresses the PV supply resource in terms of relative costs. Expressing the supply curve in terms of relative, as opposed to absolute, costs avoids the need to establish a capital cost, financing parameters, and other factors. In all cases, the cost is compared to the system with the greatest energy yield (resulting from the best location, with the best orientation). From this basic approach, it is possible to develop more complex supply curves incorporating greater variation in cost and performance parameters.

To generate a basic rooftop supply curve, two data sets are required:

1) Solar Resource Data: The solar resource and PV system performance at the expected locations and orientations

2) Rooftop Data: Available rooftop at expected locations and orientation

\subsection{Solar Resource Data and Simulations}

To determine the annual PV generation throughout the United States, we used hourly insolation values from the Typical Meteorological Year 3 (TMY3) data set from the National Solar Radiation Database (NSRDB) (NREL 2007, Wilcox and Marion 2008). We used data from 216 TMY sites in the lower 48 U.S. states, which are, with a few exceptions, the same stations used in the TMY2 data set from the original 1961-1990 NSRDB (Marion and Wilcox 1994). Although the updated NSRDB contains several hundred additional sites, the 216 original sites provide adequate coverage to capture the

\footnotetext{
${ }^{1}$ PVWATTS at http://rredc.nrel.gov/solar/codes_algs/PVWATTS/.
} 
variation in solar resources within each state. Figure 1 illustrates the location of the solar resource sites used, along with the area assigned to each site, based on the proximity of census block groups to each of the stations.

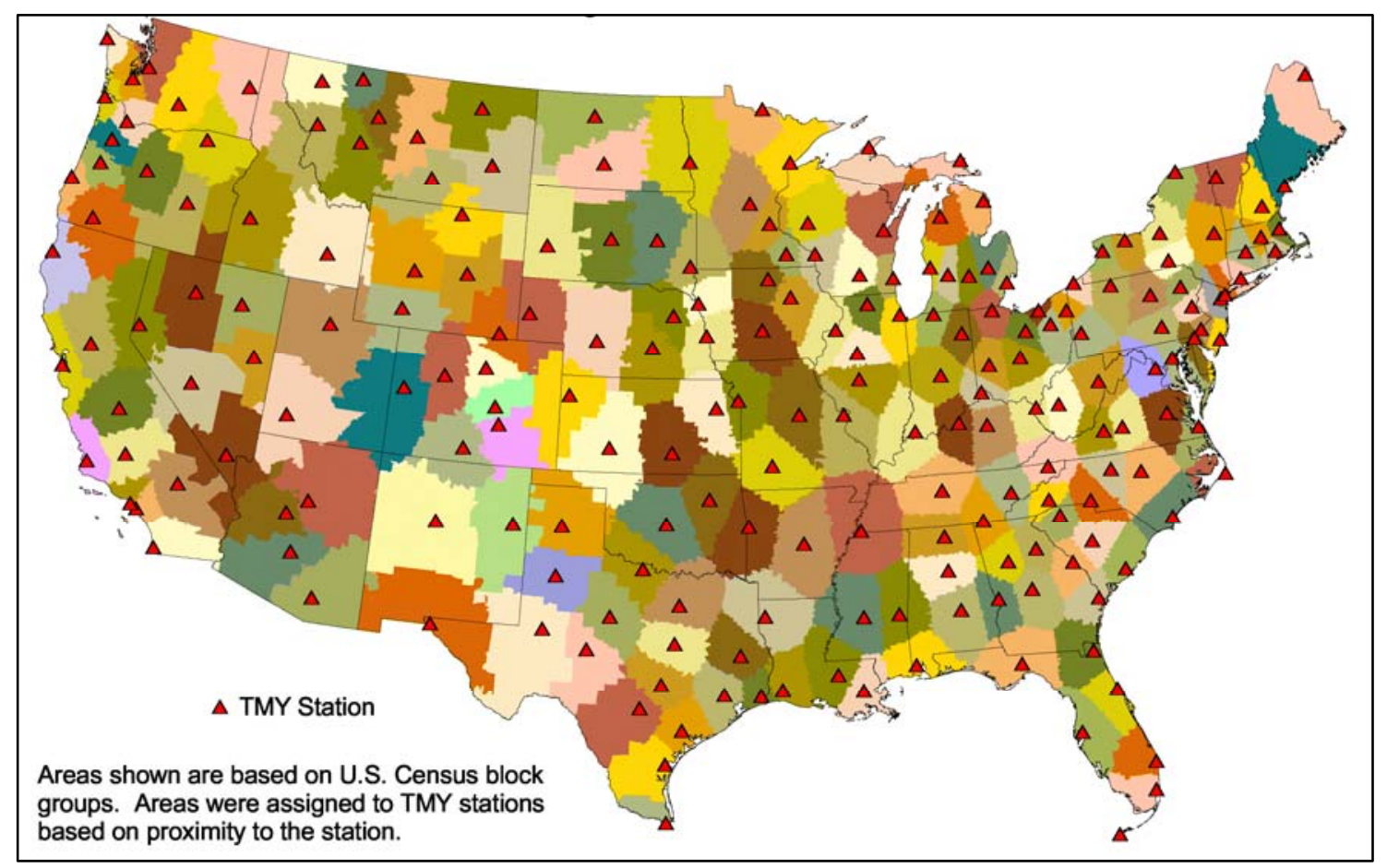

Figure 1. Solar resource locations

Solar insolation values were converted into annual solar energy production for each of the sites, using the PVWATTS/PVFORM model (Marion et. al 2005), assuming a $1 \mathrm{~kW}$ STC module, ${ }^{2}$ and average system DC-AC conversion efficiency of $77 \%$ for residential systems and $82 \%$ for commercial systems. ${ }^{3}$ To consider a wide range of roof types, nine different configurations were considered: flat, $10^{\circ}$ tilt (south facing), and $25^{\circ}$ tilt with orientations of $90^{\circ}$ (due east), $120^{\circ}, 150^{\circ}, 180^{\circ}, 210^{\circ}, 240^{\circ}$, and $270^{\circ} .4$ Actual distribution of the orientations is discussed in the next section. The best location for the simulated systems (representing the least cost step) was Alamosa, Colorado, with residential system yield of $1671 \mathrm{kWh} /$ year for a south facing, $25^{\circ}$ tilted module. ${ }^{5}$

\footnotetext{
${ }^{2}$ The module efficiency is defined under Standard Test Conditions (STC) of $1,000 \mathrm{~W} / \mathrm{m}^{2}$ solar irradiance and 25 degrees $\mathrm{C}$.

${ }^{3}$ We assume that the larger commercial systems will have a slightly more efficient inverter, as well as fewer losses associated with wiring, soiling, and overall better maintenance. The model includes variation in module efficiency that occurs due to changes in temperature, and the variation in inverter efficiency as a function of load. Additional details are available at http://rredc.nrel.gov/solar/codes algs/PVWATTS/. ${ }^{4}$ Twenty-five degrees corresponds to a roof pitch angle of about $6 / 12$, or roughly midway between the most common roof range of $4 / 12$ to $8 / 12$.

${ }^{5}$ The annual performance of the various systems is dependent not only on configuration and insolation, but also temperature. The TMY3 daily average insolation at Alamosa, Colorado, is $5.4 \mathrm{kWh} / \mathrm{m} 2 /$ day, while the best recorded TMY3 insolation is Daggett, California, with a daily average insolation of $5.7 \mathrm{kWh} / \mathrm{m} 2 /$ day. The superior PV performance at Alamosa is due to significantly lower temperatures and correspondingly higher PV efficiency during the summer.
} 


\subsection{Building Data}

The total available rooftop area was estimated for commercial and residential buildings in each state. In our base case, total floor space data for each state was obtained from McGraw-Hill, and then scaled to estimate the total building "footprint" area based on the number of floors in each building class (i.e., a three-story building with 3,000 $\mathrm{ft}^{2}$ of floor space would be assumed to have a roof footprint of $1,000 \mathrm{ft}^{2}$ ). The average number of floors per building type was based on estimates from the Energy Information Administration's 2005 Residential Energy Consumption Survey (RECS) (DOE 2001) and the 2003 Commercial Building Energy Consumption Survey (CBECS) (DOE 2003). Roof footprint is assumed to equal the roof area for flat-roofed buildings, and adjusted using a typical pitch angle to estimate roof area for sloped roofs. Because the building footprint is based on usable floor space, this eliminates roof overhang, which is not considered usable for PV.

The actual distribution between flat and tilted roofs, as well as roof orientation, was based on several factors. For residential rooftops, we assumed that $8 \%$ of all roofs are flat, based on estimates from Navigant Consulting (Paidipati et. al 2008). For commercial buildings, we used the CBECS database to estimate the distribution between flat and pitched roofs (DOE 2003). The CBECS data indicates that about $37 \%$ of commercial buildings (corresponding to about $31 \%$ of roof area) use shingles, wood, or slate; and it assumed that these roof materials are used on pitched roofs, with the remainder flat. For the orientations of pitched roofs, we assume a uniform distribution.

Total roof area was then translated into usable area using an availability factor, which accounts for shading, rooftop obstructions, and other constraints. This number is highly uncertain, and will vary regionally due to several factors including local climate and vegetation; heating, ventilation, and air-conditioning (HVAC) equipment requirements; and building density (Paidipati et. al 2008). Our base estimate is derived from Navigant Consulting data, which assumes $22 \%$ availability of roof area for residential buildings in cool climates, and $27 \%$ in warm/arid climates (due to reduced tree shading). For commercial buildings, the availability is estimated at $60 \%$ for warm climates and $65 \%$ for cooler climates.

To translate roof space into capacity for all building types, we assumed an average module efficiency of $13.5 \%$, corresponding to 135 watts per square meter of panel area for the base case (DOE 2007). When deployed on rack-mounted tilted arrays, the PV density is decreased to account for spacing between modules (Denholm and Margolis 2008). The base case PV density for flat roofs is $110 \mathrm{~W} / \mathrm{m}^{2}$, based on commercially available tilted systems. ${ }^{6}$

The product of the roof data - including size, availability, tilt, orientation, and solar array density - produces a total potential installed capacity per state. After estimating the state's total potential capacity, we then distributed the buildings (and corresponding PV

\footnotetext{
${ }^{6}$ Example of Powerlight "PowerGuard" and "PowerTilt" systems at http://www.powerlight.com/products/powertilt.php and http://www.powerlight.com/products/powerguard.php
} 
capacity) within each state to capture the variation of solar resource. For most states, this variation is small, but regional disaggregation is important for a number of states where there is significant variation, primarily larger states in the Western United States. For example, in California there is a significant difference in PV system performance across regions. Seventeen TMY sites were used in California, with the capacity factors for residential, south-facing tilted systems ranging from $13.3 \%$ to $18.8 \%$. The number of buildings in each region was determined based on population distribution, by associating each census block to the closest TMY site.

It should be noted that this basic supply curve assumes that PV fills the total usable roof area (accounting for exclusions mentioned earlier), and makes no assumptions about the economics of PV, nor restrictions on exports from the building to the grid.

\subsection{Results}

A PV capacity step is calculated for each combination of orientation and location. There are 216 resource locations, and nine orientations at each location resulting in 1,944 discrete steps on the supply curve. The size of each PV capacity step at each particular location and building orientation is the product of several factors.

Capacity at each location and orientation $=$

total state roof space corresponding to particular location $\quad \mathrm{x}$

fraction of roof in that state that is available $\quad \mathrm{x}$

fraction of state's population assigned to particular location $\quad \mathrm{x}$

fraction of buildings at particular orientation $\quad \mathrm{x}$

PV power density at particular orientation

We generated a separate capacity supply curve for residential and commercial buildings for two reasons. The first is simply to differentiate the market, and the second is to consider the very real cost differences between the two roof types. Because our costs in this simple curve are relative costs, they assume a uniform installation cost. There will be significant variation in costs for commercial systems and residential systems, so we generated a curve for each building type.

The total rooftop supply is estimated at $348 \mathrm{GW}$ for residential rooftops and 313 for commercial - or a total of about $661 \mathrm{GW}$ for the buildings sector. Figure 2 illustrates the results for the capacity supply curve as previously described. The relative cost axis is cut off at a $2 x$ scale factor for clarity, because less than $0.3 \%$ of the resource (located mostly along the Northwest coast) has a relative cost of greater than 2 . 


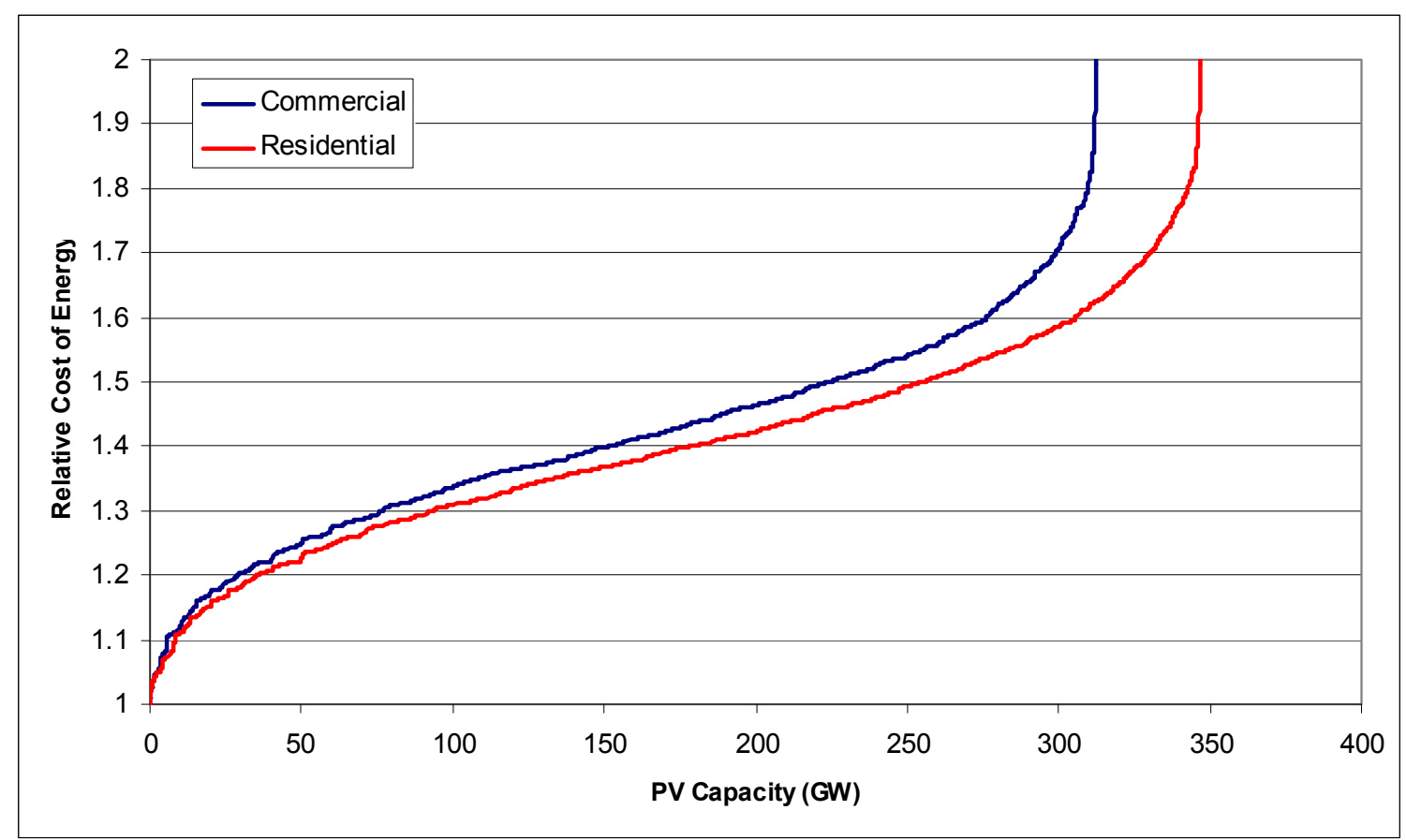

Figure 2. PV rooftop capacity supply curve for U.S. buildings in 2007

The cost of PV in 10\% steps is provided in Figure 3. The largest two single steps (1.31.5) represent about $46 \%$ of the capacity resource. 


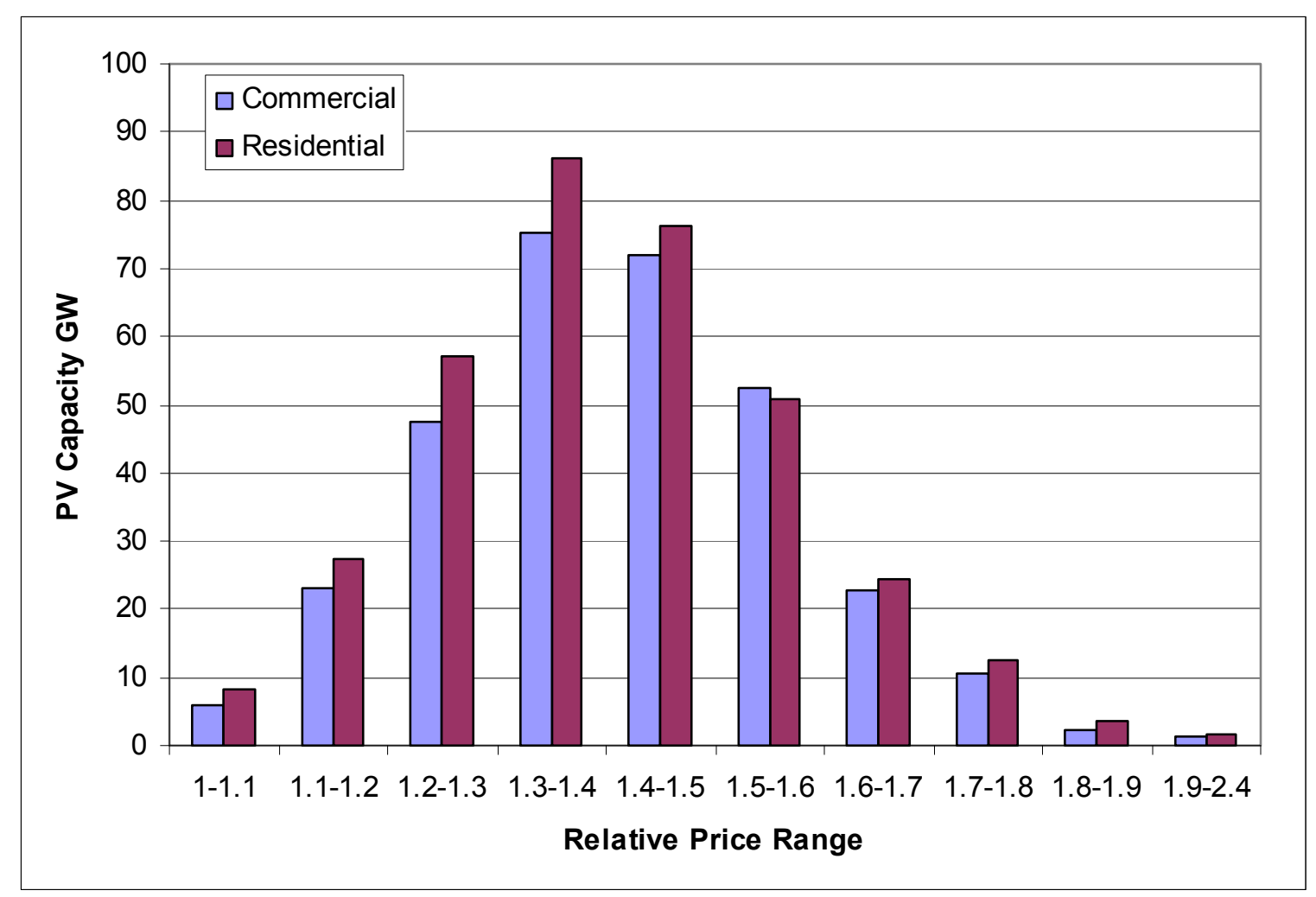

Figure 3. Distribution of PV rooftop capacity costs for U.S. buildings in 2007

The capacity curves can be converted to energy curves by multiplying the total capacity in each step by the energy produced at that location per unit capacity (Figures 4 and 5). The total annual resource is about 400 terawatt hours (TWh) for commercial and 419 TWh for residential buildings. The energy curve is shallower at the low cost of energy and steeper at the high cost, given the relative production of energy at high and low resource areas. It also should be noted that while the residential sector appears to have slightly greater potential for capacity, the amount of PV energy from the two sectors is similar. This is due to two factors: First, a greater fraction of commercial systems likely will be mounted on south-facing tilted arrays, because they are more likely to be deployed on flat roofs. Second, because commercial systems are larger, they are more likely to have higher efficiency inverters and better O\&M (especially those owned by third parties with greater motivation for output), which is captured in the higher derate factor discussed previously. Because of these factors, the average commercial system is likely to have greater output per unit of installed PV than the average residential system. 


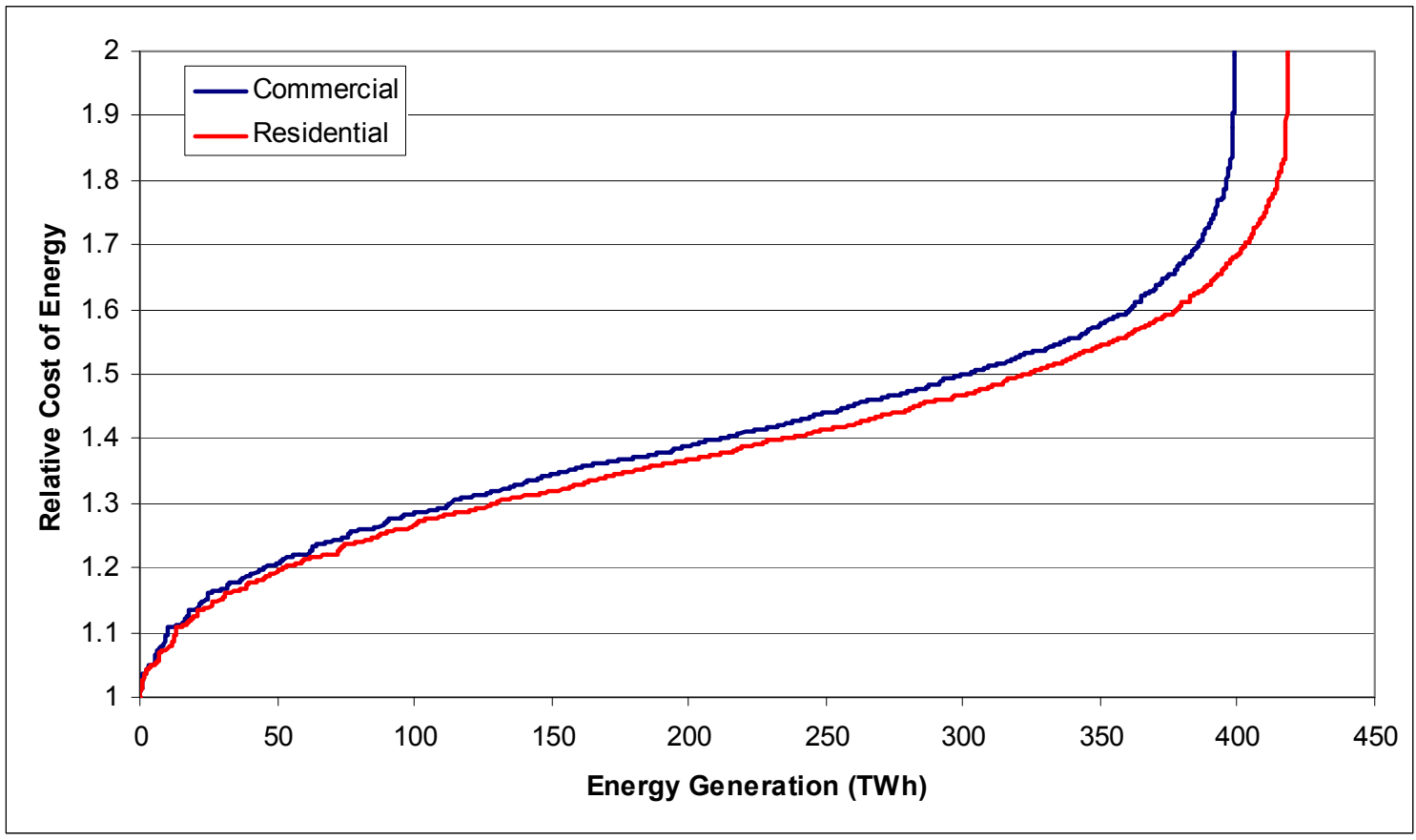

Figure 4. PV rooftop energy supply curve for U.S. buildings in 2007

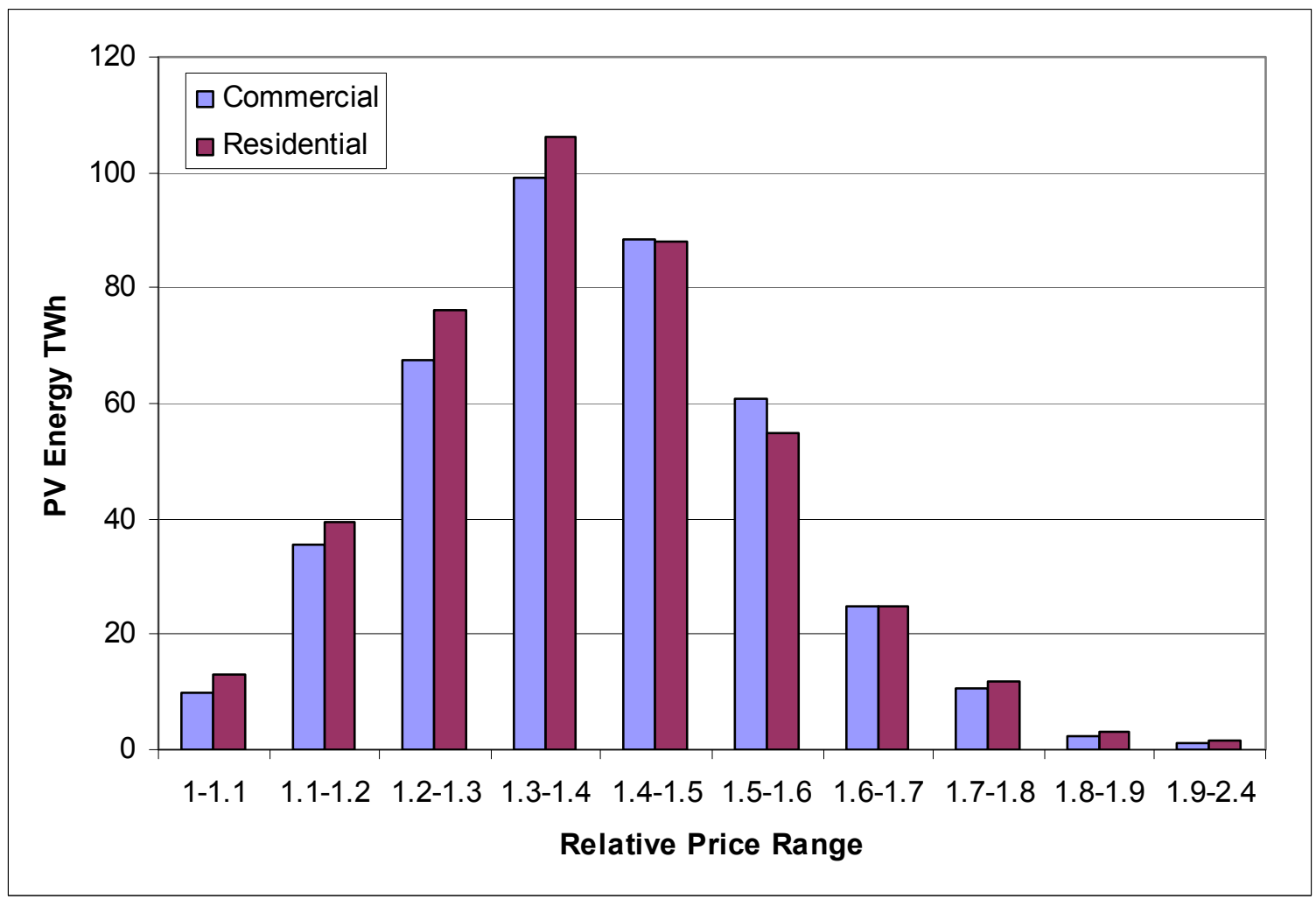

Figure 5. Distribution of PV rooftop energy costs for U.S. buildings in 2007 
To provide some context for the energy production potential, the energy supply curve can be rescaled in proportion to the total electricity demand for the United States. Figure 6 provides the relative cost of $\mathrm{PV}$ as a function of the fraction of the total 2006 demand met by PV (including industrial demand). In this curve, the residential and commercial curves are combined, and calculating the actual cost would require the appropriate weighing of the relative contribution from each. The total potential in the base case is estimated at about 819 TWh annually, which is equal to about $22 \%$ of total U.S. electric demand in 2006 (DOE 2006).

In addition to the incremental cost curve, equal to the energy cost at each step (as shown earlier), a cumulative cost curve also is provided. This curve is useful to estimate the total costs associated with meeting any specific demand level. For example, achieving $15 \%$ of the nation's demand would require moving up the incremental cost curve from the relative cost of 1 to 1.45 , meaning the last unit of PV deployed would have a cost of about 1.45 . The total cost of meeting $15 \%$ of demand with PV would be estimated using the cumulative cost curve, which is about 1.3 times the base cost.

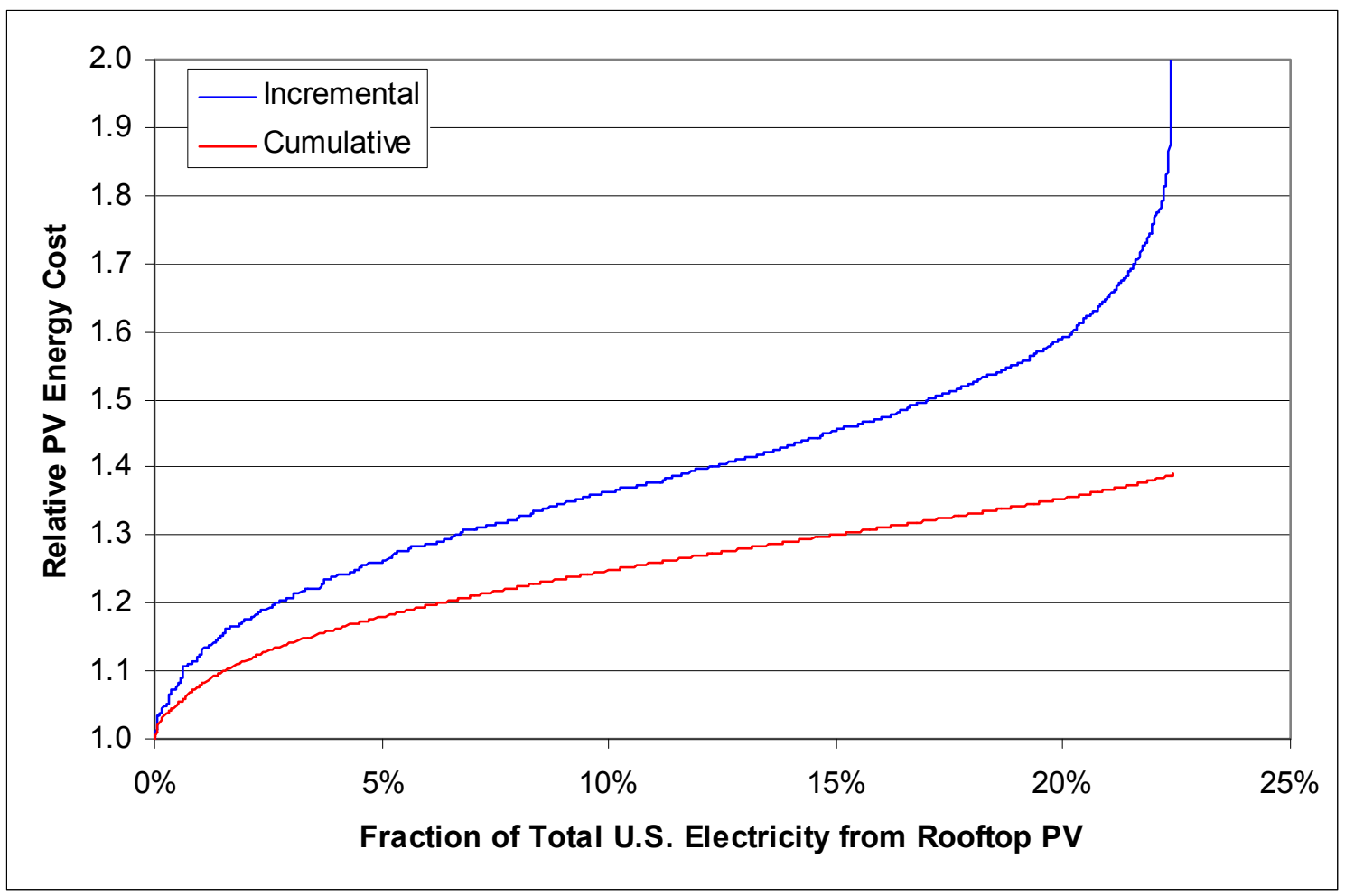

Figure 6. Combined PV rooftop energy supply curve for U.S. buildings in 2007 (compared to 2006 electricity consumption data) 


\section{Supply Curve Variations}

The results in Section 2 represent a theoretical supply curve that does not consider the uncertainty in the rooftop data, actual PV performance, and a number of constraints on actual PV installations. In this section, we consider several variations on the basic supply curve, including uncertainty in the assumptions to the base case, restrictions on the size of typical PV installations, and grid limits.

\subsection{Alternatives to the Base Scenario}

The base scenario includes a number of data sets and assumptions regarding building roof space and PV performance. There is considerable uncertainty in these values, considering actual floor space, translation of floor space to roof space, and roof availability. While it is difficult to estimate the error on the data and assumptions, it is possible to generate a "high" and "low" case based on alternative assumptions. Table 1 provides the assumptions for alternative scenarios in an attempt to bound estimates for the overall supply curve. Figures 7 and 8 provide the resulting curves for the scenarios.

Table 1. Assumptions for Alternative Scenarios

\begin{tabular}{|l|l|l|l|}
\hline & Base Case & Low Case & High Case \\
\hline $\begin{array}{l}\text { Residential Floor } \\
\text { Space }\end{array}$ & $\begin{array}{l}\text { Base Case as } \\
\text { Discussed in Text }\end{array}$ & Base Case & Base Case \\
\hline Module Efficiency & 13.5 & $10 \%$ & $20 \%$ \\
\hline $\begin{array}{l}\text { Derate Factor } \\
\text { (res./com.) }\end{array}$ & $77 \% / 82 \%$ & $77 \% / 82 \%$ & $83 \% / 87 \%$ \\
\hline Rooftop Availability & $\begin{array}{l}\text { Base Case as } \\
\text { Discussed in Text }\end{array}$ & Base - 25\% & Base $+25 \%$ \\
\hline
\end{tabular}

\footnotetext{
${ }^{7}$ The low-efficiency scenario represents the large-scale use of low-cost, thin-film technologies; whereas the high-efficiency scenario uses advanced silicon or other technologies. A discussion of various technologies and efficiencies is provided in DOE 2007.
} 


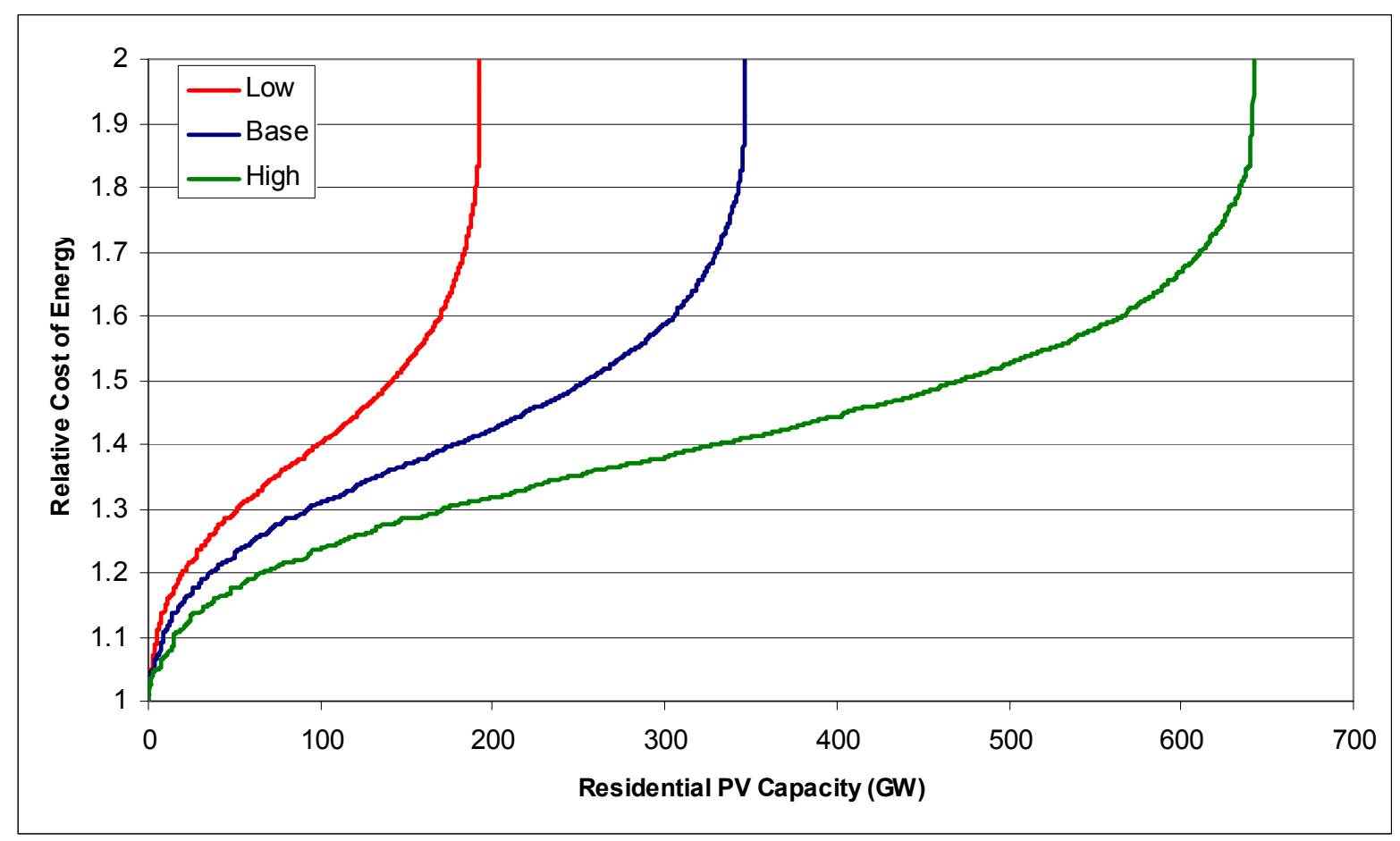

Figure 7. Alternative cases for residential roof PV supply curve

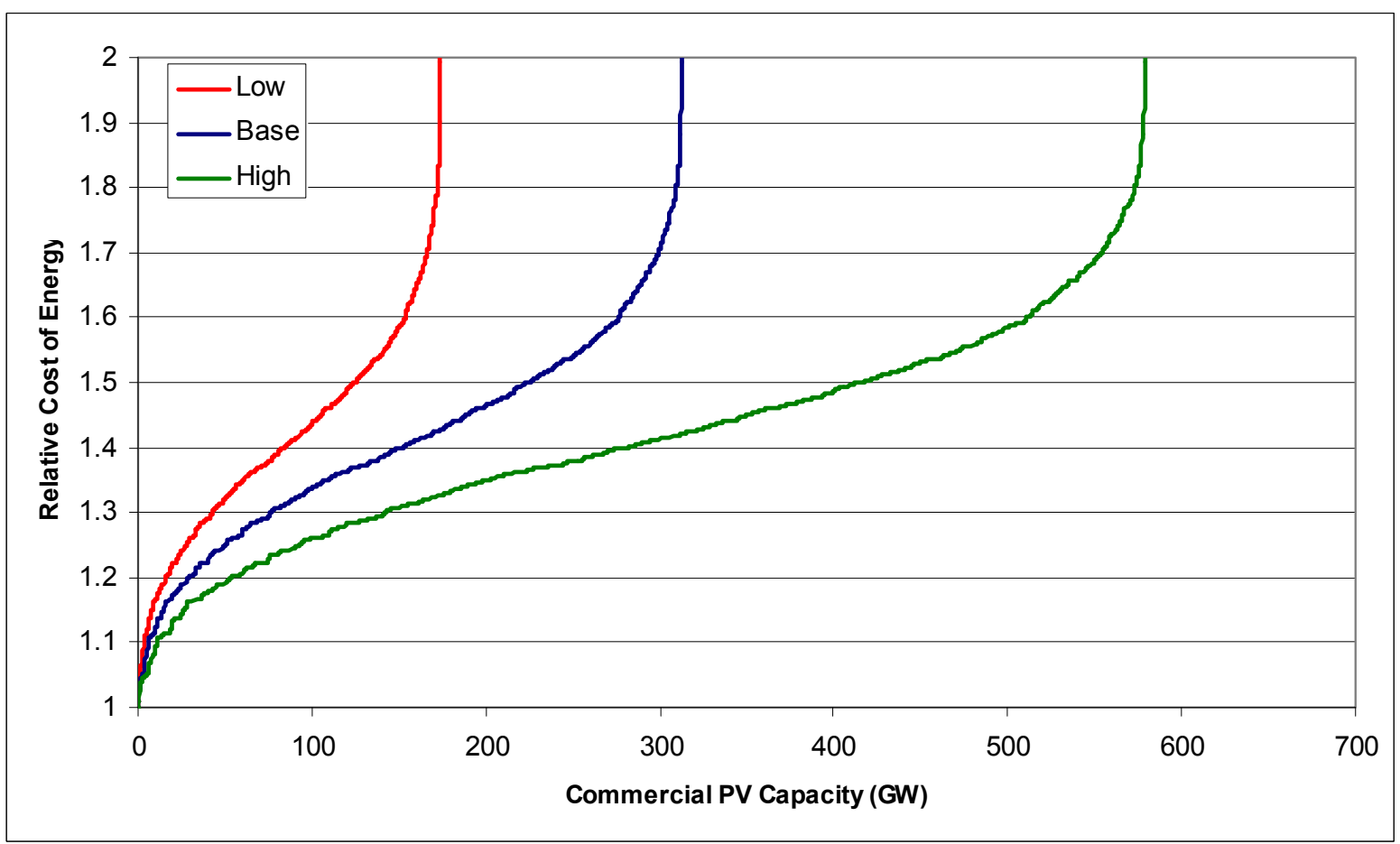

Figure 8. Alternative cases for commercial roof PV supply curve 
In addition to the changes in total capacity resulting from changing the module efficiency and rooftop availability, the energy supply curve is also sensitive to the system derate factor. The total PV energy supply curve (compared to the U.S. demand as previously illustrated in Figure 6) is provided in Figure 9. As before, the residential and commercial curves are combined, and calculating the actual cost would require the appropriate weighing of the relative contribution from each.

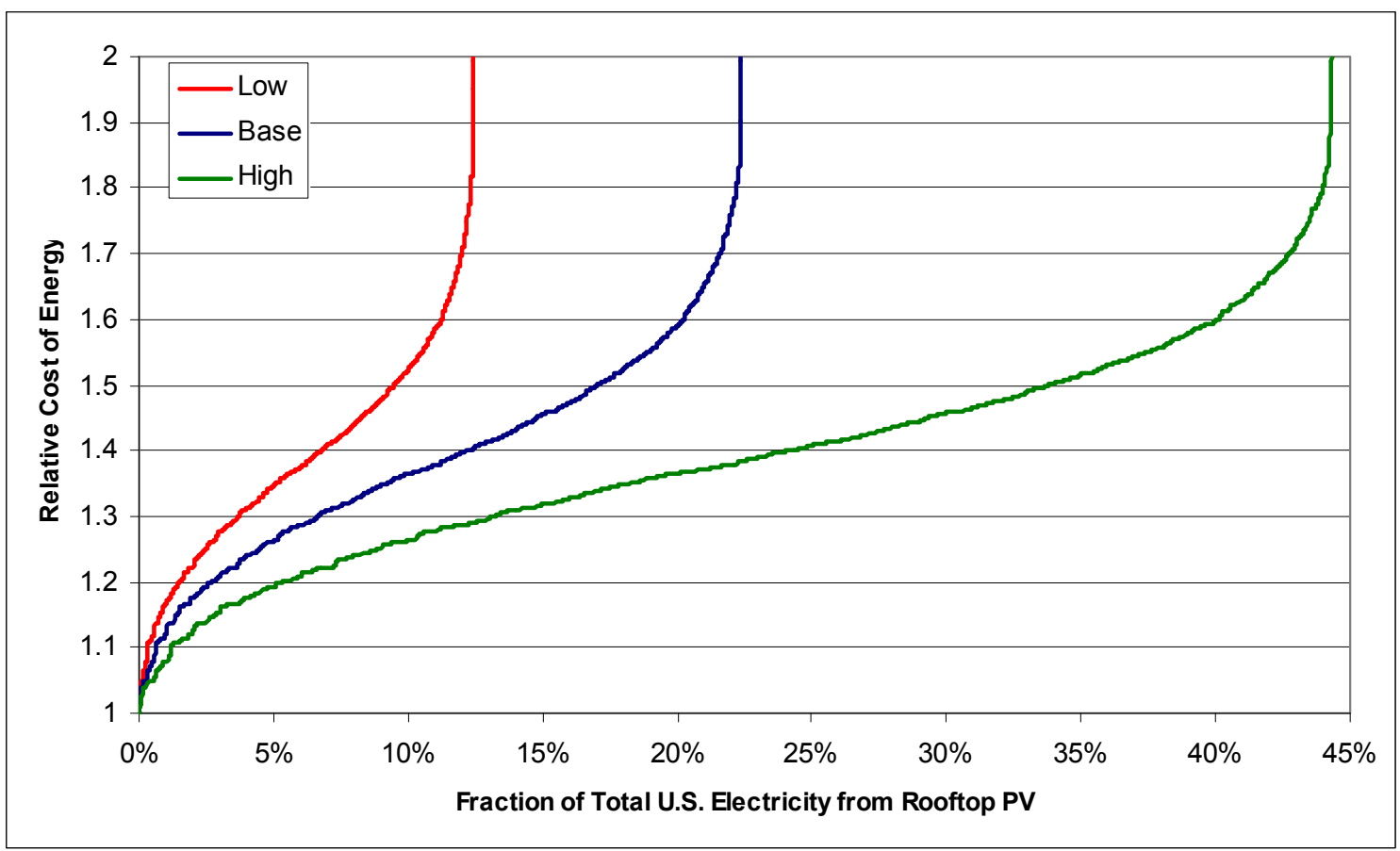

Figure 9. Alternative case combined PV rooftop energy supply curve for U.S. buildings in 2007 (compared to 2006 electricity consumption data)

\subsection{System Size}

The basic supply curve is based on the total rooftop available and the total amount of PV that could be installed if it "filled" the available roof space (considering exclusions). On residential rooftops especially, PV systems rarely fill the entire available rooftop for a variety of reasons. For example, the southerly facing rooftop on a typical detached singlefamily home might accommodate close to $10 \mathrm{~kW}$ of PV capacity if completely filled. However, a typical installation for this home type is in the range of $3-5 \mathrm{~kW}$. If the roof were totally covered with PV, much of the energy produced by this larger system could not be used by the homeowner, and would be exported to the grid. Not only would the larger system represent a much larger investment, there may be regulatory barriers to exporting this large amount of energy. ${ }^{8}$ As a result, a supply curve based on more typical installation sizes may be a more realistic assessment of what could be built on residential systems given these economic or regulatory limits.

\footnotetext{
${ }^{8}$ There are ownership structures, such as third-party or utility ownership that may warrant more complete roof coverage. Large net-metering provisions or feed-in tariffs also may incentivize larger systems.
} 
To estimate the impact of reducing the available rooftops, we produced an alternative supply curve for residential buildings. Instead of using the total roof area, we used census data to estimate the total number of housing units of six types in each state: detached, attached, apartments with two to four units, apartments with five or more units, and mobile homes. The distribution of these buildings within each state was based on population distribution, as estimated previously. After determining the number of homes in each region, we estimated the fraction of homes with available roofs, and then assigned a typical PV system size to each home.

The majority of housing units in the United States are single-family homes, constituting about $66 \%$ of all residences. We assumed an average size of $5 \mathrm{~kW}$ on detached homes, and $3 \mathrm{~kW}$ on attached homes; we assigned a $2 \mathrm{~kW}$ system on the remaining home types. The actual availability of individual homes due to shading and other obstructions is highly uncertain, with few reliable estimates beyond a number of "engineering estimates" provided in the literature (Denholm 2007). We used two estimates of roof availability: a high case where assumed availability is $70 \%$ for homes in the Southwestern states, and $50 \%$ in the remaining states; and a low case where $50 \%$ and $25 \%$ of homes are available in the two regions. The distribution of roof pitches and orientations was identical to those in the basic supply curve.

Figure 10 illustrates the resulting restricted residential rooftop supply curves. Compared to the base case, the total capacity has been reduced from $348 \mathrm{GW}$ to between 145 and $256 \mathrm{GW}$, a reduction of about $50 \%$.

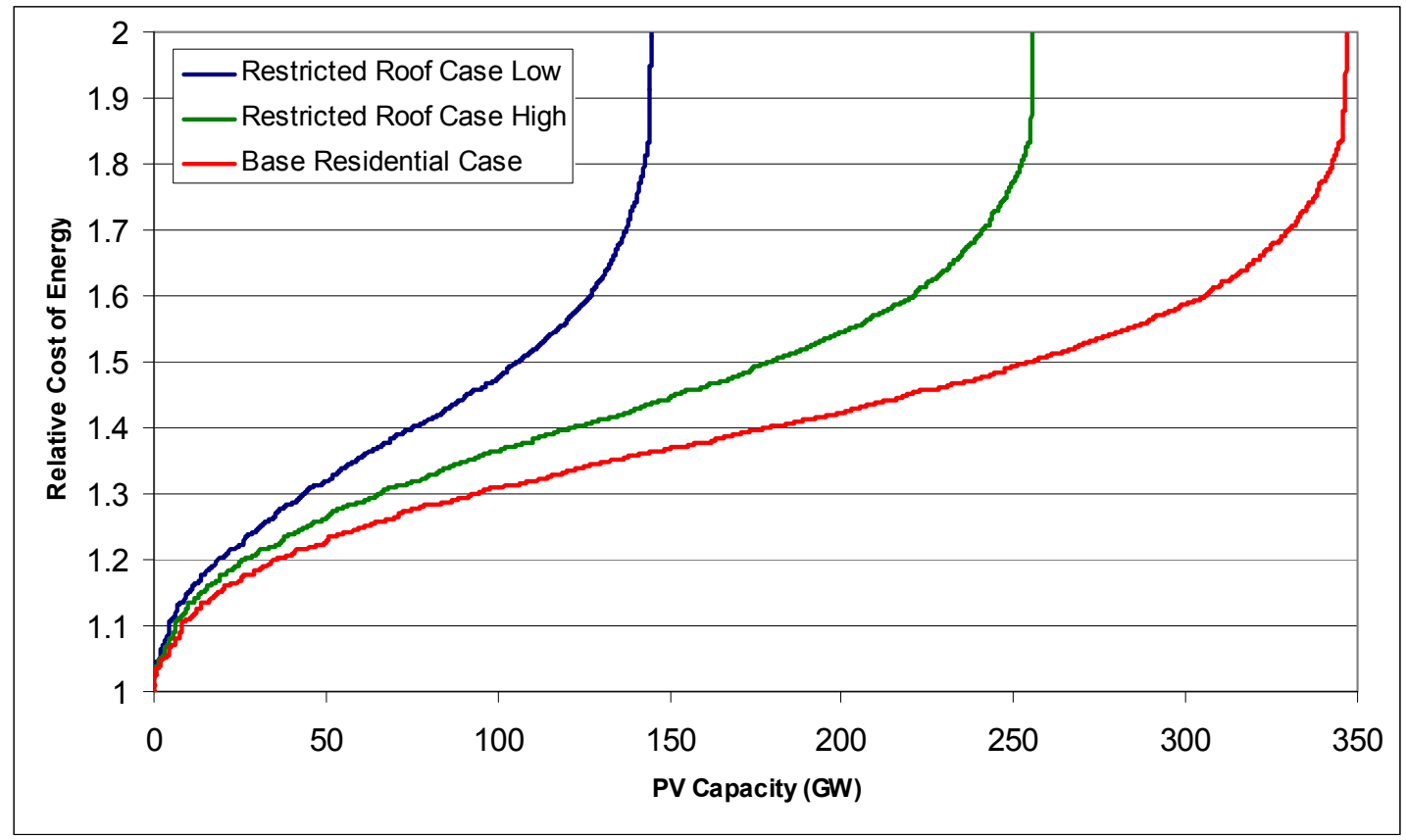

Figure 10. Size-restricted PV rooftop capacity supply curve for residential buildings 
It is difficult to estimate the impact of roof restrictions on commercial buildings. As with residential buildings, completely filling the roof may be economically nonoptimal for a variety of reasons. However, these large roof areas may be a better fit for alternative ownership structures discussed previously, and roof restrictions may be less constraining.

\subsection{Overall System Limits}

An additional factor that may restrict PV deployment (or increase costs) is the limitations of integrating variable sources into the existing grid. In Figure 9, illustrated previously, the base rooftop supply curve could provide up to about $23 \%$ of the nation's current demand. A previous study of PV in the current Electric Reliability Council of Texas (ERCOT) grid found potential challenges to integrating PV at that level of supply (Denholm and Margolis 2007a). Providing more than this amount is possible, but will require changes to system flexibility - and, ultimately, may require deployment of enabling technologies. It is not possible to determine the additional costs associated with enabling technologies - some, such as real-time pricing, will have low to zero costs; while others, such as energy storage, would add substantial costs (Denholm and Margolis 2007b).

While these costs cannot be precisely identified, the fractional energy supply curve (Figure 9) can be used to at least consider where operation of the grid might be affected by large-scale deployment. One of the challenges of this estimation is the fact that electricity can be transmitted - if too much generation occurs in a high-resource area, this energy potentially could be used in a region with lower-quality resource. The ultimate limit on transmission, however, is the lack of substantial interconnection among the three U.S. grids (the Eastern Interconnect, Western Interconnect, and ERCOT). ${ }^{9}$ To examine a limiting case, the total supply curve was separated into three grids (Figure 11).

\footnotetext{
${ }^{9}$ In our simulations, we assumed ERCOT is all of Texas, but about $15 \%$ of the Texas population actually lives outside of ERCOT.
} 


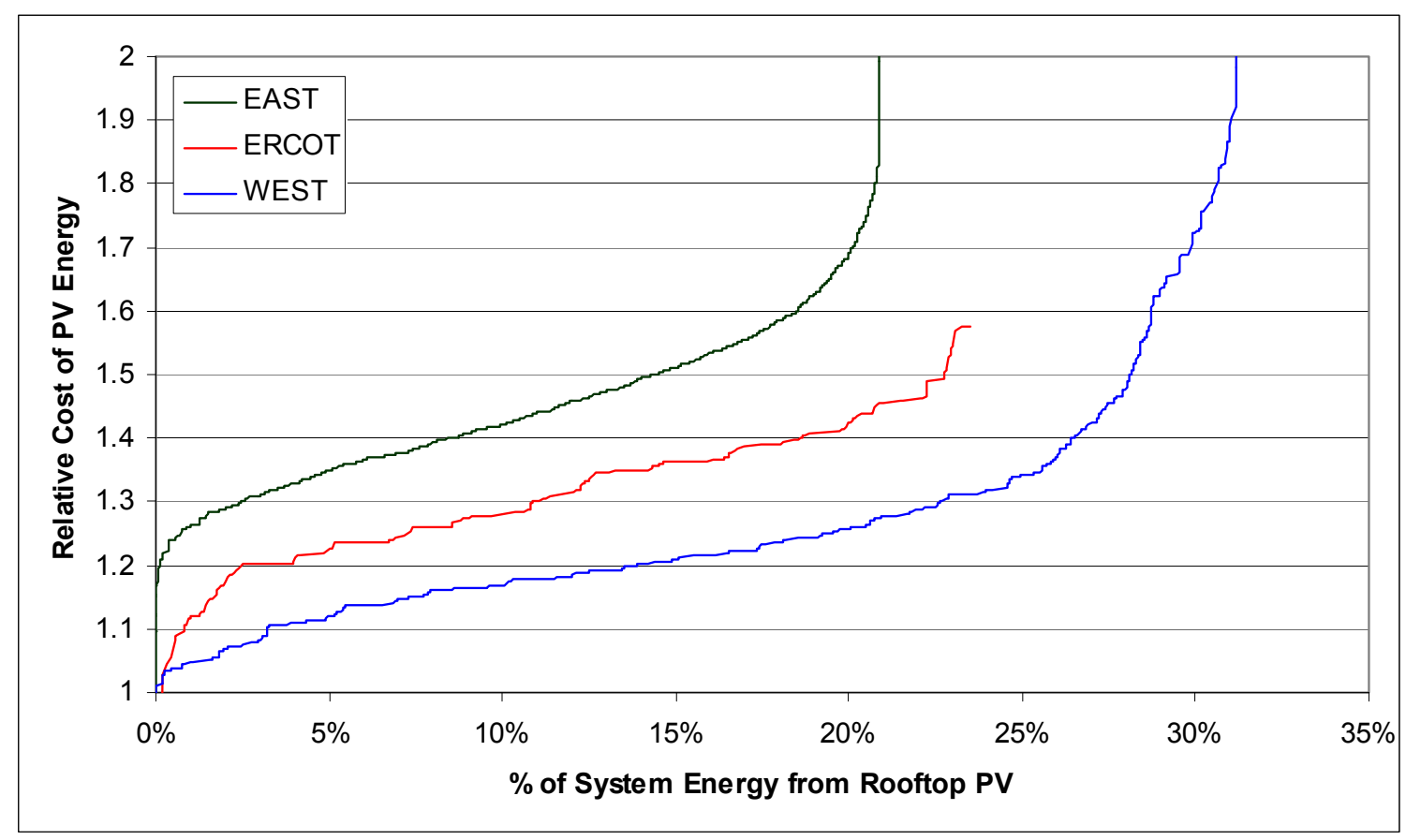

Figure 11. Fractional energy PV rooftop supply curve for three U.S. interconnects

The variation in fractional load met by PV among the three grids is primarily a function of resource quality, although there are some building-related differences as well commercial buildings in the Eastern United States tend to have less roof space per unit of floor space.

\subsection{Other PV Deployment Options}

The supply curves presented here do not consider a multitude of other building-related deployment options. Additional areas potentially suitable for PV deployment include industrial buildings, parking lot and other awnings, as well as vertical surfaces on buildings.

As noted at the beginning of this report, deriving a land-based PV supply curve is difficult given the enormity of the resource. However, generating a land-based supply curve should be possible by using land-screening factors previously applied to concentrating solar power (eliminating land unsuitable for development due to population, environmental, and other restrictions) (Mehos et. al 2007). This methodology would allow comparing the cost of solar PV generation in the best locations with those closer to major load centers, and evaluation of associated issues such as the cost of new transmission development. 


\section{Discussion and Conclusions}

The PV supply curves generated in this work are the product of a series of factors, with varying uncertainty. Areas of fairly low uncertainty include the variation in solar resource and the regional distribution of buildings. Areas of higher uncertainty include the distribution of building orientations and PV energy density, especially considering the continued improvement in module efficiency. Perhaps the highest uncertainty is rooftop availability and fraction of buildings that can accommodate an average-size PV system.

To be useful, our relative cost supply curve must be translated into an absolute cost supply curve, using not only the capital cost of the installed system, but also the type of financing used by the building owner. Both of these factors will vary regionally, but the financing will vary tremendously, with some residential owners having access to lowinterest home equity-type loans with tax-deductible interest, and others paying much higher rates. On the commercial side, financing also will have a significant impact on the net price of systems depending on whether the owner is able to take advantage of accelerated depreciation and other benefits.

Once the absolute cost has been evaluated, the system then can be compared to the cost of grid electricity. This calculation can be used to generate a "demand curve," which would estimate the potential market size at various PV system costs. A PV demand curve may be useful not only to determine the potential market size, but also the potential for PV to mitigate fossil fuel dependency and climate change. 


\section{References}

Denholm, P. (2007). “Technical Potential of Solar Water Heating to Reduce Fossil Fuel Use and Greenhouse Gas Emissions in the United States.” NREL/TP-640-41157.

Denholm, P. and R. M. Margolis. (2008). "Land-Use Requirements and the Per-Capita Solar Footprint for Photovoltaic Generation in the United States." Energy Policy, 36, 3531-3543.

Denholm, P. and R. M. Margolis. (2007a) "Evaluating the Limits of Solar Photovoltaics (PV) in Traditional Electric Power Systems.” Energy Policy, 35, 2852-2861.

Denholm, P. and R. M. Margolis. (2007b) "Evaluating the Limits of Solar Photovoltaics (PV) in Electric Power Systems Utilizing Energy Storage and Other Enabling Technologies." Energy Policy, 35, 4424-4433.

Department of Energy, U.S. (DOE). (2007). "Solar energy technologies program multiyear program plan 2007-2011." Accessed 2008 at http://www1.eere.energy.gov/solar/pdfs/set myp 2007-2011 proof 1.pdf

DOE. (2006). "Electric power annual 2006," Energy Information Administration, Washington, D.C., DOE/EIA-0348(2006).

DOE. (2003). “Commercial Building Energy Consumption Survey 2003,” Energy Information Administration, Washington, D.C. Accessed 2008 at http://www.eia.doe.gov/emeu/cbecs/contents.html

DOE. (2001). "Residential Energy Consumption Survey 2001," Energy Information Administration, Washington, D.C. Accessed 2008 at http://www.eia.doe.gov/emeu/recs/

Gallagher, P.; M. Dikeman; J. Fritz; E. Wailes; W. Gauther; and H. Shapouri. (2003). "Biomass from Crop Residues: Cost and Supply Estimates." U.S. Department of Agriculture, Office of the Chief Economist, Office of Energy Policy and New Uses. Agricultural Economic Report No. 819.

Kline, D.; D. Heimiller, and S. Cowlin. (2008). “A GIS Method for Developing Wind Supply Curves.” NREL/TP-670-43053.

Marion, B.; M. Anderberg; P. Gray-Hann. (2005). "Recent Revisions to PVWATTS." NREL/CP-520-38975.

Marion, W. and S. Wilcox. (1994). "Solar Radiation Data Manual for Flat-Plate and Concentrating Collectors," NREL/TP-463-5607

McGraw-Hill Construction Analytics (2008). "Building Stock Database.” 
Mehos, M. S. and D.W. Kearney. (2007). "Potential Carbon Emissions Reductions from Concentrating Solar Power by 2030." Chapter in "Tackling Climate Change in the U.S.: Potential Carbon Emissions Reductions from Energy Efficiency and Renewable Energy by 2030.” Kutscher, C. F., ed.; Boulder, CO: American Solar Energy Society, pp. 79-89; NREL Report No. CH-550-41270.

National Renewable Energy Laboratory (NREL). (2007). "National Solar Radiation Database 1991-2005 Update: User's Manual.” NREL/TP-581-41364. Accessed 2008 at http://rredc.nrel.gov/solar/old data/nsrdb/1991-2005/

Paidipati, J.; L. Frantzis; H. Sawyer; and A. Kurrasch. (2008). "Rooftop Photovoltaics Market Penetration Scenarios.” NREL/SR-581-42306

Rosenfeld, A. H., et al. (1993). "Conserved Energy Supply Curves for U.S. Buildings.” Contemporary Policy Issues, (11), 45-68

Wilcox, S. and Marion, W. (2008). "Users Manual for TMY3 Data Sets," NREL/TP-58143156, revised May 2008 


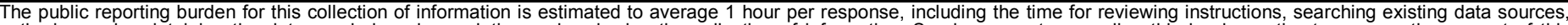

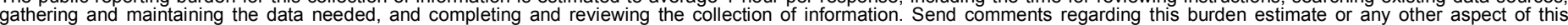

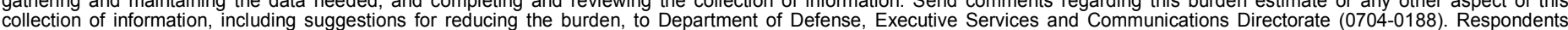

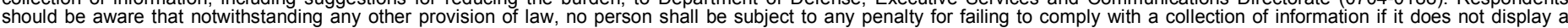

should be aware that notwithstanding

PLEASE DO NOT RETURN YOUR FORM TO THE ABOVE ORGANIZATION.

\begin{tabular}{l|l|l|} 
1. REPORT DATE $(D D-M M-Y Y Y Y)$ & 2. REPORT TYPE & 3. DATES COVERED (FrOm - TO)
\end{tabular}

November 2008

Technical Report

4. TITLE AND SUBTITLE

Supply Curves for Rooftoop Solar PV-Generated Electricity for the United States 5a. CONTRACT NUMBER

DE-AC36-08-GO28308

5b. GRANT NUMBER

5c. PROGRAM ELEMENT NUMBER

5d. PROJECT NUMBER

NREL/TP-6A0-44073

5e. TASK NUMBER

PVB7.6301

5f. WORK UNIT NUMBER
7. PERFORMING ORGANIZATION NAME(S) AND ADDRESS(ES)

National Renewable Energy Laboratory

1617 Cole Blvd.

Golden, CO 80401-3393
8. PERFORMING ORGANIZATION REPORT NUMBER

NREL/TP-6A0-44073

9. SPONSORING/MONITORING AGENCY NAME(S) AND ADDRESS(ES)

10. SPONSOR/MONITOR'S ACRONYM(S) NREL

11. SPONSORING/MONITORING AGENCY REPORT NUMBER

12. DISTRIBUTION AVAILABILITY STATEMENT

National Technical Information Service

U.S. Department of Commerce

5285 Port Royal Road

Springfield, VA 22161

13. SUPPLEMENTARY NOTES

14. ABSTRACT (Maximum 200 Words)

Energy supply curves attempt to estimate the relationship between the cost of an energy resource and the amount of energy available at or below that cost. In general, an energy supply curve is a series of step functions with each step representing a particular group or category of energy resource. The length of the step indicates how much of that resource is deployable or accessible at a given cost. Energy supply curves have been generated for a number of renewable energy sources including biomass fuels and geothermal, as well as conservation technologies. Generating a supply curve for solar photovoltaics (PV) has particular challenges due to the nature of the resource. The United States has a massive solar resource base - many orders of magnitude greater than the total consumption of energy. In this report, we examine several possible methods for generating PV supply curves based exclusively on rooftop deployment.

\section{SUBJECT TERMS}

energy supply curves; solar photovoltaics; PV; solar; rooftop PV; energy consumption; building technologies; residential buildings; solar systems

\begin{tabular}{|c|c|c|c|c|}
\hline \multicolumn{3}{|c|}{ 16. SECURITY CLASSIFICATION OF: } & \multirow{2}{*}{$\begin{array}{l}\text { 17. LIMITATION } \\
\text { OF ABSTRACT } \\
\text { UL }\end{array}$} & \multirow{2}{*}{$\begin{array}{l}\text { 18. NUMBER } \\
\text { OF PAGES }\end{array}$} \\
\hline $\begin{array}{l}\text { a. REPORT } \\
\text { Unclassified }\end{array}$ & $\begin{array}{l}\text { b. ABSTRACT } \\
\text { Unclassified }\end{array}$ & $\begin{array}{l}\text { c. THIS PAGE } \\
\text { Unclassified }\end{array}$ & & \\
\hline
\end{tabular}

19a. NAME OF RESPONSIBLE PERSON

19b. TELEPHONE NUMBER (Include area code) 